\title{
Economía social, entre la economía pública y la privada capitalista
}

\author{
Alejandro Martínez Charterina \\ Catedrático de la Universidad de Deusto \\ Director del Instituto de Estudios Cooperativos de la Facultad de Derecho
}

Sumario: I. Introducción. II. Orígenes de la economía social. III. Enfoques conceptuales: economía social y sector no lucrativo (non profit organizations). IV. La economía solidaria, como tercer enfoque. V. Componentes de la economía social. VI. La Confederación empresarial española de economía social. VII. La Ley de Economía Social: concepto de economía social. VIII. Entidades que forman la economía social en España en la Ley de 2011. IX. Algunos datos actuales. X. Consideraciones finales. XI. Bibliografía.

Resumen: La economía social, que tiene sus orígenes en el siglo XIX, renació en el último cuarto del siglo xx de forma que su presencia ha ido extendiéndose y su importancia ha crecido hasta que nuestro país se ha dotado de una Ley de economía social. Junto al debate conceptual en la medida que la economía social agrupa una variedad de empresas de estatutos jurídicos diversos, se debe reconocer en ella junto a su aportación económica, en tanto que lleva a cabo una actividad económica respetuosa con el medio y sostenible acomodada a unos principios, su dimensión social y solidaria, su aportación al desarrollo local, y su aptitud para encarar los problemas actuales.

Palabras clave: Economía Social, Economía Social y Solidaria, Tercer Sector, Cooperativismo.

Abstract: Social economics, which dates back to the nineteenth century, underwent rebirth in the last quarter of the twentieth century. It has become widespread and so influential that our country has passed a law on social economics. In addition to the conceptual debate on social economics including a variety of companies with different legal statutes, its contribution to local development and capacity to focus on current problems must be acknowledged. Its economic contribution, as business which is respectful with the environment and sustainable while adhering to principles and its social and solidary dimension are key factors.

Keywords: Social economics, social and solidary economy, third sector, cooperativism. 


\section{Introducción}

A finales de los años ochenta del pasado siglo escribía yo la frase siguiente: "estamos presenciando el renacimiento de la economía social como respuesta a una serie de demandas de la sociedad civil ante la crisis económica, así como la tendencia hacia unos valores relativos a la forma de vida y al cambio ideológico de la sociedad» ${ }^{1}$.

En aquellos años ochenta se había puesto de actualidad de nuevo, por ello renacimiento, la economía social. Esto sucede en la práctica, toda vez que nacen y se transforman muchas empresas en el ámbito de la economía social, las cuales, además, son capaces de relacionarse entre sí y, en ocasiones, de asociarse. También renace la economía social en el espacio doctrinal, dado el interés en las Universidades y su presencia en publicaciones. Pero del mismo modo se hace presente en el terreno político, especialmente a través de la experiencia francesa. En este sentido está la Ley francesa «relativa al desarrollo de ciertas actividades de economía social» de 20 de julio de 1983, las referencias a la economía social en el noveno Plan francés, la creación de la Delegación interministerial para la economía social, y la obra de Thierry Jeantet «La modernisation de la France par l'economie sociale» (Paris, 1986), bien expresiva en su título, y también en su contenido, del papel llamado a desempeñar por la economía social.

Desde entonces el interés por el tema no ha dejado de acrecentarse, hasta llegar a la aprobación en nuestro país de la Ley 5/2011, de 29 de marzo, de economía social, que entró en vigor el pasado 30 de abril de 2011.

\section{Orígenes de la economía social}

La economía social hunde sus raíces en el siglo XIX en el contexto del proceso de industrialización. Las primeras entidades de la economía social nacen como reacción a las consecuencias de la denominada revolución industrial.

A juicio de Henri Desroche, el término economía social se remonta a la obra de Charles Dunoyer "Nouveau Traité d'Economíe Sociale», que fue publicado en $1830^{2}$.

1 Alejandro Martínez Charterina, Análisis de la integración cooperativa (1990), p. 65.

2 Henri Desroche, Pour un traité d'Economie Sociale (1983), p. 17. 
El término cobrará importancia y popularidad a finales del siglo XIX, y especialmente a partir del encargo que recibió Charles Gide para realizar un informe para la Exposición Universal de París de 1900 sobre «La Economía Social en la Exposición Universal»³.

Como consecuencia del éxito del término, como indica Desroche, muchas obras de principios del siglo xx se identificaron como economía social, con sentidos distintos ${ }^{4}$.

Sin embargo, por razones diversas, algún autor habla del abuso del término "social» ${ }^{5}$, otros, seguramente con mayor justificación, del triunfo del Estado en el debate entre el Estado y la Sociedad Civil6, se dejará de hablar de economía social, abriéndose un paréntesis de casi cincuenta años, desde el comienzo del segundo cuarto del siglo XX hasta la crisis de los años setenta.

Desde estos orígenes lejanos, y dejando aparte las distancias que median con la economía de interés general alemana7, los orígenes próximos de la economía social son franceses.

Existe un deseo de superación de los valores imperantes en las economías desarrolladas en busca de la descentralización a través de las economías locales, la aplicación de tecnologías intermedias, de nuevas formas de trabajo, de la acomodación de la producción a las necesidades, en sintonía con la apreciación del valor de la persona y del medio ambiente en el que transcurre su vida, al mismo tiempo que se busca un modo de hacer que supere las carencias del capitalismo y de la gestión pública, lo que vendrá a situar a la economía social entre la economía pública y la economía privada capitalista8.

Los promotores de la economía social, en el marco de la situación de recesión de los años setenta a partir de la crisis del petróleo, actuarán con decisión tratando de ocupar un puesto importante en la sociedad a través de la fórmula que resurge.

3 Puede verse en Thierry Jeantet y Roger Verdier, L'Economie Sociale (1982), p. 26.

4 Henry Desroche, O.C., p. 99 ss.

5 Jean-Michel Saillant hace esta referencia en el artículo «A la recherche de I'Economie Sociale», en Revue des études coopératives (1983), p. 88.

6 François Boursier, «Aux origines de l'Economie Sociale», en Après-Demain (1985), p. 6.

7 Gemeinwirtschaft, que agrupa al sector público y parapúblico, de forma que no es asimilable, por consiguiente, a la economía social; Walter Hesselbach, Las empresas de economía de interés general (1978), p. 160, considera en ella cuatro grupos: empresas públicas, empresas de construcción de viviendas de interés general, cooperativas, y empresas del sector libre de la economía de interés general.

8 Michel Maree y Marie-Anne Saive, Economie sociale et renouveau coopératif: definition, financement, enjeux (1983), p.16. 
En la primera parte de la década de 1970 se produce un acercamiento entre los movimientos cooperativo y mutualista franceses, que vuelven a redescubrir elementos comunes entre ambos, y poco después se unirá a ellos el movimiento asociativo, de forma que en 1975 se creará el Comité National de Liaison des Activités Mutualistes, Coopératives et Associatives (CNLAMCA), que impulsará la publicación en 1980 de la Carta de la Economía Social.

Con los siete artículos de la Carta, que constituye una verdadera declaración de principios, «un gran número de personas en Francia aceptaban las condiciones de desarrollo integral del hombre, su voluntad de ser dueño de su destino, su aspiración a trabajar de otra forma (no convencional), en grupos pequeños, con solidaridad entre todos y responsabilidad de todos» ${ }^{9}$.

A partir de la publicación de la Carta llega el reconocimiento de los poderes públicos, con la creación en 1981 de la Delegación Interministerial para la Economía Social (DIES), que pasará a depender de una Secretaría de Estado para la Economía Social, se creará la Fundación de la Economía Social (FONDES), también en 1981, y un organismo de financiación, el Instituto para el Desarrollo de la Economía Social (IDES), en 1983.

Desde Francia se extenderá la idea de la economía social hacia el norte, a Bélgica, a través de un centro de estudio e investigación vinculado a la Universidad de Lieja, el CIRIEC, que promoverá un encuentro de las organizaciones de economía social en 1982 (se creará el Consejo Walón de Economía Social en 1989), y también hacia el sur, a España, a través de la creación de la sección española del CIRIEC, en 1986, y a otros varios países con secciones nacionales del CIRIEC.

\section{Enfoques conceptuales: economía social y sector no lucrativo (non profit organizations)}

No resulta fácil definir la economía social acotando un sector plural en el que pueden tratar de instalarse muchas realidades que poseen estatutos jurídicos muy distintos ${ }^{10}$.

9 Alejandro Martínez Charterina, o.c., p. 68.

10 Piénsese que entre la economía pública y la economía privada capitalista, que se considerará como una primera aproximación, se pueden encontrar múltiples figuras, como las siguientes: economía alternativa, economía de donaciones, economía autogestionaria, economía de la solidaridad, economía popular, economía popular solidaria, economía del trabajo, economía de interés general (en Alemania), economía social, ter- 
En los primero momentos se consideraba esta dificultad en Francia, no sólo por la disparidad de empresas con estatutos jurídicos diversos, sino también por la expectativa de una economía social con carácter experimental, dado que el impulso social animaba a pensar que nuevas formas podían hacerse presentes en el futuro.

Por ello en primera instancia se pretenderá definir la economía social en negativo, señalando qué no es economía social. Así se considera la economía social aquella que está situada entre la economía pública y la privada capitalista, es decir, lo que no es, ni economía pública ni privada capitalista. De este modo se identifica economía social con tercer sector, y se vendrán a utilizar las dos expresiones como sinónimos.

Este primer enfoque del tercer sector, debe advertirse, no lleva aparejada la renuncia al beneficio por parte de las entidades de economía social, ni tampoco que puedan ocupar espacios de frontera con el sector público ${ }^{11}$.

Respecto al primer punto se trata de considerar en su justo término la oposición a la economía privada capitalista, y para ello puede resultar útil la distinción entre empresa de servicios y de resultados que Georges Fauquet aplicó a la cooperativa, la cual necesita capitalizarse y obtener beneficios para poder llevar a cabo su actividad y mantenerla en el tiempo, pero lo que se pretende es prestar un buen servicio, siendo el beneficio la consecuencia y no el objetivo, ello frente a la empresa de resultados que pretende el beneficio como objetivo de su actividad ${ }^{12}$.

Precisamente por eso, el reparto del beneficio no se llevará a cabo en función del capital aportado, que es lo que caracteriza a la empresa capitalista, ni las decisiones se tomarán tampoco en función del capital aportado.

Respecto al segundo punto se trata de salvar algunas posibles situaciones fronterizas en las que se hace presente algún tipo de parti-

cer sector, sector no lucrativo (non profit sector), economía solidaria, sector voluntario, sector asociativo, sector independiente, sector informal, sector caritativo, sociedad civil, sector de las organizaciones no gubernamentales, sector intermedio, sector de actividades filantrópicas... Puede verse en este sentido José Luis Monzón et al. (dirs.), El tercer sector no lucrativo en el Mediterráneo. La Economía Social de no mercado (2003), tomo I, p. 13, y la aproximación terminológica al concepto de economía solidaria que hacen Marta Enciso y José Luis Retolaza en la obra colectiva del Instituto de Derechos Humanos La economía solidaria y su inserción en la formación universitaria (2004), pp. 19 ss.

11 Alejandro Martínez Charterina, o.c., pp. 70-71.

12 Georges Fauquet, «Le secteur coopératif», en Oeuvres (1965), pp. 72, 74 y 80. 
cipación pública, como sucede en las «régies coopératives» (cooperativas públicas belgas) o en las asociaciones gestoras de servicios públicos, cuando se trata de identificar economía social con tercer sector ${ }^{13}$.

Ese primer enfoque trata de ser superado con una definición en positivo, que diga qué es economía social, no sólo qué no es. Así, Claude Vienney selecciona elementos comunes compartidos entre los distintos estatutos jurídicos de los considerados componentes de la economía social, como son el asociacionismo, la voluntariedad, y el comportamiento distinto del capitalismo, cuando dice que la economía social reúne «...agrupaciones voluntarias de personas, que organizan y hacen funcionar como empresas actividades colectivas que les son necesarias o que juzgan útiles, sin que el poder que ellas ejercen allí ni el beneficio que obtienen estén unidos a las partes sociales que suscriben o al montante de las cotizaciones que entregan para tomar parte» ${ }^{14}$.

El Comité Nacional de Enlace de las Actividades Mutualistas, Cooperativas y Asociativas (CNLAMCA) define economía social como el conjunto de entidades no pertenecientes al sector público que, con funcionamiento y gestión democráticas e igualdad de derechos y deberes de los socios, practican un régimen especial de propiedad y distribución de las ganancias, empleando los excedentes de ejercicio para el crecimiento de la entidad y la mejora de los servicios a los socios y a la sociedad ${ }^{15}$. Se aprecian notas de finalidad de servicio a los miembros y a la colectividad, autonomía de gestión, primacía de las personas y del trabajo sobre el capital, y procesos democráticos de gestión.

Para Thierry Jeantet ${ }^{16}$ seis principios y un cuasi-principio delimitan la economía social, a saber,

— libre asociación de individuos,

- gestión democrática,

- no acumulación individual de beneficios,

- solidaridad interna y externa,

- calidad de los servicios y productos,

— desarrollo del individuo por la formación y la cultura,

- y, como cuasi-principio, el federalismo.

13 Michel Maree y Marie-Anne Saive, o.c., pp. 22-23.

14 «Concepts et champs de l'Economie Social», en Revue des études coorératives, n. ${ }^{\circ} 9$ (1983), 50 ss.

15 José Luis Monzón Campos, «La economía social en España», en CIRIEC España, n. ${ }^{\circ} 0$ (1987), p. 22.

16 Thierry Jeantet, La modernisation de la France par l'économie sociale (1986), p. 19. 
Se puede destacar la proximidad de estos principios con los principios cooperativos, lo que pone de manifiesto que cuanto mayor sea la pretensión de delimitar el sector, mayor ha de ser el problema de encaje de la realidad dinámica que constituye la economía social ${ }^{17}$.

En términos más recientes, la Carta de la Economía Social de la Social Economy Europe, anterior Conferencia Europea Permanente de Cooperativas, Mutualidades, Asociaciones y Fundaciones, estableció en 2002, ante las diferentes formas jurídicas variables de un país a otro, unas características comunes de las organizaciones de economía social:

— primacía de la persona y del objeto social sobre el capital;

- adhesión voluntaria y abierta;

- control democrático por sus miembros;

- conjunción de los intereses de los miembros usuarios y del interés general;

— defensa y aplicación de los principio de solidaridad y de responsabilidad;

- autonomía de gestión e independencia de los poderes públicos;

- destino de la parte principal de los excedentes a la consecución de objetivos de desarrollo sostenible, de interés de los servicios a los miembros y del interés general ${ }^{18}$.

Estos principios han sido acogidos por el Comité Económico y Social Europeo, así como por el Parlamento Europeo ${ }^{19}$, y vienen recogidos de forma textual también en el Preámbulo de la Ley de la Economía Social de 2011 y son aplicados en su artículo 4, relativo a los principios orientadores de las entidades de economía social.

Por su parte, el informe Chaves-Monzón del Comité Económico y Social de 2008, La Economía Social en la Unión Europea, define ésta como

Conjunto de empresas privadas organizadas formalmente, con autonomía de decisión y libertad de adhesión, creadas para satisfacer las necesidades de sus socios a través del mercado, produciendo bienes y servicios, asegurando o financiando y en las que la eventual distribución entre los socios de beneficios o excedentes así como la toma de decisiones, no están ligados directamente con el capital o cotizaciones aportados por cada socio, correspondiendo un voto a cada uno de ellos. La Economía Social también agrupa a aquellas entidades privadas organizadas formalmente con autonomía de decisión y libertad de

17 Alejandro Martínez Charterina, o.c., p. 73.

18 Social Economy Europe, Charte de l'économie sociale (2002).

19 José Luis Monzón (dir.), Las grandes cifras de la economía social en España (2010), p. 27. 
adhesión que producen servicios de no mercado a favor de las familias, cuyos excedentes, si los hubiera, no pueden ser apropiados por los agentes económicos que las crean, controlan o financian. ${ }^{20}$

Cabe hablar, pues, de dos partes en la economía social, la parte empresarial o de mercado y la parte de no mercado (asociaciones y fundaciones al servicio de los hogares).

Justamente esta distinción nos facilita el acercamiento al segundo enfoque que la teoría ha elaborado acerca del tercer sector, el sector no lucrativo (non profit organizations-NPO).

A diferencia de la economía social, este enfoque tiene su origen en los Estados Unidos, en investigaciones de los años setenta ${ }^{21}$, y su extensión se produce a través de los países anglosajones.

Según este enfoque 22 , señala Beatriz Calderón, el punto de partida es el altruismo (no lucrativo), justamente lo contrario de las exigencias del capital en una sociedad capitalista. Y junto a ello se asientan otros elementos como disponer de una estructura formal, ser una institución privada, tener capacidad de autogobierno y disponer de algún tipo de aportación voluntaria en dinero, en especie, en trabajo voluntario23.

Este enfoque al no aceptar las organizaciones que distribuyen beneficios a sus socios deja fuera del tercer sector a algunas que son acogidas en la economía social, del mismo modo que ésta no considera organizaciones de no beneficio que carecen de organización democrática.

20 José Luis Monzón (dir.), o.c. (2010), ps. 28-29. Esta definición proviene de otra anterior adoptada por la Comisión Científica del CIRIEC-España, que recogía lo siguiente: "se entiende por economía social al conjunto de empresas privadas creadas para satisfacer las necesidades de sus socios a través del mercado, produciendo bienes y servicios, asegurando o financiando y en las que la distribución del beneficio y la toma de decisiones no están ligadas directamente con el capital aportado por cada socio, correspondiendo un voto a cada uno de ellos. La economía social también incluye a las instituciones sin fines de lucro que son productores no de mercado privados (ISFLSH), no controlados por las administraciones públicas y que producen servicios no destinados a la venta para determinados grupos de hogares, procediendo sus recursos principales de contribuciones voluntarias efectuadas por los hogares en su calidad de consumidores, de pagos de las administraciones públicas y de rentas de la propiedad», en Rafael Chaves y José Luis Monzón, «Las cooperativas en las modernas economías de mercado: perspectiva española», en Economistas (2000), p. 115.

21 Como la de B.A. Weisbrod, "Toward a theory of the voluntary non-profit sector in a three sector economie» (1975).

22 Puede verse L. Salamon y H. Anheier, In search of the nonprofit sector: The cuestion of definitions.(1992), también J.I. Ruiz Olabuénaga, El sector no lucrativo en España (2000).

23 Beatriz Calderón Milán, «Dimensión económica del sector no lucrativo en las regiones españolas», en CIRIEC España n. ${ }^{\circ} 50$ (2004), p. 236. 


\section{La economía solidaria, como tercer enfoque}

Una tercera aproximación conceptual puede acercarnos a lo que se conoce en nuestro ámbito como economía solidaria, teniendo en cuenta que existe una terminología muy rica y variada, como hemos considerado anteriormente.

El origen se remonta a unas jornadas que realizó Traperos de Emaús en Pamplona en 1989, en las que se utiliza el término de Empresa Social Marginal (y el de minusvalía social)24.

En 1994 en Beire (Navarra) se organizaron unas Segundas Jornadas por Aurkilan y Gaztelan, en las que la denominada Empresa Social Marginal pasó a llamarse Empresa Social Solidaria (para dejar de automarginarse).

Esta Empresa Social Solidaria se caracteriza por ser una empresa de inserción, no lucrativa (aunque rentable, de beneficios para el crecimiento propio o de otros en solidaridad), participada (y para ello de formación), y ecológica (trabajo limpio, energía mínima, contaminación mínima, reciclaje, comercio equitativo, consumo consecuente).

En ese tiempo, 1992, se creó en Bélgica la Red Europea de Economía Alternativa y Solidaria, con cincuenta redes de todo el mundo, a partir de lo cual, en los Primeros Encuentros sobre Economía Solidaria, en Córdoba, en 1995, se constituyó la Red de Economía Alternativa Solidaria (REAS) en España.

Desde los encuentros sobre economía solidaria, cada dos años, y la Carta Emprender por un mundo solidario elaborada por ocho centros de Bélgica, Francia y España y aceptada por los agentes del ámbito de la empresa social solidaria, se irá pasando de ésta empresa social solidaria a la Economía Solidaria.

El Foro Social de Porto Alegre se encargará de extender el término por los países de idioma español.

Desde la Carta del Emprendedor por un Mundo Solidario se formulan para la economía solidaria los siguientes principios:

— igualdad de los protagonistas;

- objetivo de crear empleo estable (y favorecer a los desfavorecidos);

— no perjudicar el medio ambiente;

- cooperación frente a competencia;

— sin ánimo de lucro, promoción humana y social:

24 Seguimos en esta aproximación a la economía solidaria a Marta Enciso y José Luis Retolaza en Instituto de Derechos Humanos, o.c., pp. 31 ss. 
- compatible con beneficio (no pérdida)

- que no se reparte para beneficio particular;

- compromiso con el entorno, implicación en redes, y solidaridad hacia un modelo socioeconómico alternativo.

Junto a ellos se recogen criterios complementarios, que no se encuentran presentes en todas las entidades, pero se consideran por muchas criterios de buena práctica que concretan los generales, entre ellos:

— entidad integrada en su medio;

- autónoma respecto a poderes públicos, y a terceros;

- crítica con los excesos;

- mantiene relaciones comerciales justas;

- transparencia informativa;

- abanico salarial definido;

- compromiso con la calidad;

- reflexión sobre el voluntariado, caso de haberlo;

- apoyo a iniciativas solidarias.

La economía solidaria considera que asume los principios cooperativos, pero se diferencia y aporta al resto de la economía social su carácter solidario particularizado en la no búsqueda del beneficio de los socios, sino de terceros, a los cuales se dirige precisamente la actuación de la entidad, mediante la prestación de servicios o mediante la inclusión (es decir, frente a la solidaridad interna, la solidaridad externa). Se habla así de un ámbito específico dentro de la economía social denominado economía solidaria.

Aunque tiene mucho en común con las NPO (non profit organizations) por la ausencia de ánimo de lucro, parte de las entidades no se podrían incluir entre ellas por su forma jurídica mercantil.

Con todo, sin embargo, se ha comenzado a hablar del término socioeconomía solidaria como un intento de ampliar la estructuración de una alternativa utópica solidaria, de la mera economía a todos los ámbitos sociales. "La irrupción de entidades no vinculadas directamente con la actividad económica, grupos de voluntariado, partidos políticos, sindicatos, organizaciones públicas, asociaciones culturales, de ocio, Ilevarían a una ampliación de tal concepto, que indudablemente desbordaría el ámbito de la economía social». ${ }^{25}$

25 Instituto de Derechos Humanos, o.c., p. 41. 
En cierto modo estas ideas nos presentan a la economía social y solidaria como complementaria a la intervención del sector público en la economía ${ }^{26}$, a través de:

- Producción de servicios de utilidad colectiva, con ventajas, como la proximidad al medio local y el conocimiento de las necesidades nuevas, la rapidez en la intervención, la mano de obra más barata (a través de la presencia de un voluntariado sin coste), mayor implicación de la personas, etc., que conviven con riesgos como la existencia de fondos propios pequeños, las dificultades de financiación y crédito, la posible falta de profesionalidad en el voluntarismo, etc.

- Redistribución (no sólo a través de asociacionismo humanitario o caritativo). Servicios a precio inferior o a distintos precios en el ejercicio de la solidaridad. El voluntariado representa también una forma de redistribución por su propia naturaleza, aunque no se aprecie corrientemente.

- Defensa del empleo a través de la solidaridad cooperativa, la reinserción de trabajadores con dificultad, la readaptación de trabajadores (a través de labores educativas), la ayuda para la creación de empresas y el emprendimiento en general (formación de emprendedores).

- Importancia de los comportamientos éticos por parte de sus componentes.

Esta última consideración ética, unida a la existencia de principios directores de las actividades de economía social, la consideración de una economía de valores, invita a pensar que la justicia social y el sentido común pueden atemperar el egoísmo de las personas, lo que acrecienta el valor de esta economía solidaria.

\section{Componentes de la economía social}

Para Henri Desroche 27 existen siete categorías de empresas componentes del sector de la economía social, de las que tres son componentes principales y cuatro son fronterizas de la economía social con otros sectores.

26 Jacques Defourny, "Orígenes, contextos y funciones de un tercer gran sector», en Monzón y Defourny (dir.), Economía Social. Entre economía capitalista y economía pública (1992), ps. 98 ss.

27 Henri Desroche, o.c. (1983), pp. 204-206. 
Los tres componentes principales son la empresa cooperativa, la mutualista y la asociativa.

A partir de ello propone unas interfases de conexión con otros sectores alrededor del núcleo central de los tres ${ }^{28}$.

Una primera interfase conecta la economía social con el sector público: cooperativa, mutua o asociación concertada con servicios públicos, si el concierto permite una autonomía de gestión. Así, por ejemplo, los conciertos del sector hospitalario con asociaciones privadas.

Una segunda entre la economía social y el sector municipal, si la gestión de ciertas actividades municipales se lleva a cabo con una asociación municipal o una comunidad de barrio.

La tercera interfase se produce entre la economía social y el sector privado tradicional; cuando la empresa privada concierta una participación de los trabajadores en la propiedad, en la gestión, en los resultados.

Una conexión, por fin, entre la economía social y el sector sindical, a través de empresas gestionadas por sindicatos, como sucede en Alemania e Israel, y de otras actividades sindicales en materia de formación o de turismo social.

Esta representación plural y variable de la economía social permite adaptarse fácilmente a las diversas realidades de los distintos países y a sus evoluciones.

También sintoniza con la idea de algunos autores que destacan como una nota importante de la economía social su flexibilidad, capacidad de adaptarse y transformarse según las circunstancias, de acuerdo con las consideraciones conceptuales anteriores.

\section{La confederación empresarial española de economía social}

En nuestro país se constituyó en 1992 la Confederación Empresarial Española de Economía Social (CEPES) como plataforma representativa de los agentes de la economía social. Integra en la actualidad a 29 organizaciones de cooperativas, sociedades laborales, mutualidades, asociaciones y fundaciones de carácter empresarial, cofradías de pescadores, empresas de inserción y centros especiales de empleo.

Cabe señalar que para la Confederación Española de Economía Social, desde su creación, es esencial el componente económico de las entidades de la economía social, pero el componente social es el que confiere a dichas entidades una dimensión específica y diferenciadora en su forma de hacer empresa.

28 Jacques Defourny, o.c., (1992), pp. 90 ss. 
La Confederación CEPES considera a la economía social como toda actuación económica que actúa en el mercado o en la sociedad, y que, independientemente de su forma jurídica, comparte unos principios de organización democrática, de consideración a la persona por delante del capital, de reparto horizontal de la propiedad, de reparto de beneficios con criterio colectivo, y se muestra especialmente solidaria con el entorno, siendo provocadora de cohesión social.

La aprobación por unanimidad de todos los grupos parlamentarios del Congreso de los Diputados de la Ley 5/2011, de 29 de marzo, de Economía Social, ha supuesto para la Confederación Española de Economía Social, que la venía pidiendo de forma reiterada, según palabras de su Presidente, "un punto de inflexión normativo e institucional para el movimiento de la Economía Social española, siendo un reflejo de la sensibilidad política y social hacia las demandas históricas del sector» ${ }^{29}$.

\section{La Ley de Economía Social: concepto de economía social}

La Ley de Economía Social de 29 de marzo de 2011 se aprobó con la intención de dotar de un marco jurídico, que reconozca y confiera visibilidad a la economía social, así como una mayor seguridad jurídica, con respeto a las normas específicas aplicables a las entidades que la integran, y de facilitar la determinación de las medidas de fomento correspondientes a las mismas ${ }^{30}$.

El artículo segundo define la economía social como «el conjunto de actividades económicas y empresariales, que en el ámbito privado llevan a cabo aquellas entidades que, de conformidad con los principios recogidos en el artículo 4, persiguen bien el interés colectivo de sus integrantes, bien el interés general económico o social, o ambos».

Unas actividades económicas, en el ámbito privado, vinculadas a unos principios de comportamiento, y sujetas a un fin de bien colectivo y/o general, constituyen la esencia de esta economía social.

¿Cuáles son esos principios a los que las entidades de la economía social han de acomodar sus actividades? Los recoge el artículo cuarto:

29 Juan Antonio Pedreño, «Valoración de la Ley 5/2011 de Economía Social», en Cuadernos de Economía Social, n. ${ }^{\circ} 1$ (2011), p. 2.

30 Ley 5/2011, de 29 de marzo, de Economía Social, en el Preámbulo, III, así como en el artículo primero. 
- En primer lugar la gestión autónoma y transparente, democrática y participativa de la entidad, y ello en base a que se desea anteponer la persona al capital y el fin social a los intereses individuales.

- A continuación, la aplicación de los resultados de la actividad a los miembros de la entidad en función de lo realizado, trabajo, actividad, servicio..., por ellos, así como al fin social que se considere; es decir, el reparto no capitalista.

- Un principio de solidaridad interna y externa (hacia dentro y hacia fuera de la entidad) que facilite el desarrollo local, la igualdad de oportunidades entre hombres y mujeres, la cohesión social, la inserción de personas en riesgo de exclusión, el empleo estable y de calidad, la conciliación de la vida personal, familiar y laboral, y la sostenibilidad.

— Finalmente, la independencia de los poderes públicos.

\section{Entidades que forman la economía social en España en la Ley de 2011}

El artículo cinco de la Ley recoge las entidades de la economía social, a saber: cooperativas, mutualidades, fundaciones y asociaciones que realicen actividades económicas, sociedades laborales, empresas de inserción, centros especiales de empleo, cofradías de pescadores, sociedades agrarias de transformación, entidades singulares creadas ad $h_{0}{ }^{31}$, así como las incluidas en el Catálogo de entidades de economía social, que según el artículo sexto, elaborará y mantendrá actualizado el Ministerio de Trabajo e Inmigración.

Estas entidades, conforme al artículo séptimo, podrán asociarse, y las asociaciones podrán agruparse, para la representación y defensa de sus intereses.

Podemos detenernos en una referencia sintética de estas entidades de economía social.

- La cooperativa es una sociedad empresarial que lleva a cabo su actividad económica ajustándola al cumplimiento de siete principios, la voluntariedad, la gestión democrática, la participación económica de los socios (que supone el interés limitado al capi-

31 Como es el caso de la Organización Nacional de Ciegos Españoles (ONCE), que recoge como tal entidad singular de economía social la disposición adicional tercera de la Ley. 
tal y el reparto de excedentes en función de la actividad desarrollada, no del capital aportado), la autonomía e independencia, la educación, la cooperación entre cooperativas, y el interés por la comunidad, que le deben conducir a la consecución y al seguimiento de unos valores de autoayuda, autorresponsabilidad, democracia, igualdad, equidad, solidaridad, honestidad, transparencia, responsabilidad y vocación sociales, que conjuntamente conforman su identidad ${ }^{32}$.

- La mutualidad es una sociedad de personas, sin ánimo de lucro, de estructura y gestión democrática, que ejerce una actividad que proporciona determinados servicios a los asociados o mutualistas. Cabe destacar en ella el carácter voluntario, participativo, solidario y mutual. Los servicios plurales, seguros, previsión de enfermedad, invalidez, muerte, jubilación, accidentes..., que reciben los mutualistas se financian con sus propias aportaciones periódicas.

- Una fundación es una organización dispuesta por sus fundadores (uno o varios) que pretende alcanzar unos fines de interés general para un grupo de beneficiarios en ausencia de ánimo de lucro, mediante la gestión por un órgano colegiado (Patronato) de un patrimonio y sus rentas dotado en origen por los fundadores y acrecentado en el tiempo, cuyo destino necesario ha de ser el cumplimiento de los fines fundacionales.

- Una asociación es una agrupación de personas que comparten intereses comunes y se unen para realizar una actividad colectiva de forma estable, independiente, democrática y sin ánimo de lucro. Tanto las asociaciones como las fundaciones persiguen fines de interés general y carecen de ánimo de lucro, si bien el elemento personal de la asociación predomina en cuanto los asociados beneficiarios manifiestan su voluntad y la gestionan, $y$, del mismo modo proveen a la financiación de sus actividades con sus cuotas (además de otros posibles ingresos), al margen de una voluntad y un patrimonio fundacionales, que limitan la autonomía de la gestión en las fundaciones.

- La sociedad laboral es una sociedad anónima o de responsabilidad limitada en la que la mayor parte del capital es propiedad de los trabajadores, ningún socio puede tener más de un tercio del mismo (salvo ausencia de ánimo de lucro que permite al

32 Puede verse el resultado del Congreso centenario de la Alianza Cooperativa Internacional, celebrado en Manchester, en 1995, en Declaración de la Alianza Cooperativa Internacional sobre la identidad cooperativa (1996). 
socio llegar hasta el 50\%). Deben tener un mínimo de capital de $60.102 €$, si se trata de una sociedad anónima laboral, o de $3.006 €$, si se trata de una sociedad de las de responsabilidad limitad laboral.

- Las empresas de inserción son organizaciones sin ánimo de lucro que producen bienes y servicios llevando a cabo actividades intensivas en mano de obra con la finalidad de integrar en el mercado ordinario de trabajo a personas en situación o riesgo de exclusión social ${ }^{33}$. Con esa razón de ser constituyen estructuras de aprendizaje que puedan posibilitar el acceso al empleo de colectivos desfavorecidos a través de un proceso de inserción, estableciéndose durante el mismo una relación laboral convencional con las personas beneficiarias del mismo.

- Los centros especiales de empleo son empresas formadas en al menos un $70 \%$ de la plantilla por personas con discapacidad superior al 33\%, que asumen un compromiso de formación para los trabajadores discapacitados, y que realizan una actividad económica en el mercado, para promover al empleo a trabajadores discapacitados. Estos centros, además de financiarse con el resultado de su actividad económica, reciben ayudas de las Administraciones Públicas en razón a su aportación social.

- Las cofradías de pescadores son corporaciones de derecho público que están formadas por los armadores de buques de pesca y los trabajadores del sector, tienen personalidad jurídica y capacidad de obrar, y actúan como órganos de consulta y colaboración de las Administraciones Públicas en materia de pesca marítima y organización del sector de la pesca, prestan servicios a sus miembros, representan sus intereses, y administran sus recursos patrimoniales formados por las cuotas de sus miembros, transferencias, donaciones y rentas de su patrimonio 34 .

- Las sociedades agrarias de transformación son sociedades civiles con personalidad jurídica y capacidad de obrar desde su inscrip-

33 Destacan en ellas características de organización no lucrativa, que asume el riesgo de empresa, que crea puestos de trabajo de forma transitoria, que mantiene un compromiso fuerte con la comunidad, y realiza una función educativa. En Carmen Marcuello, y otros, Informe sobre las empresas e inserción en España (2008), pp. 11 a 13.

34 Algunas características las hacen especialmente adecuadas para participar en la economía social toda vez que colaboran en el mejor nivel de vida de las comunidades de pescadores artesanales y su integración social. Puede verse en Ángel Cervera Paz, Análisis estratégico de las cofradías de pescadores en el marco de la economía social (2006), p. 18. 
ción en el correspondiente Registro para la producción, transformación y comercialización de productos agrícolas, ganaderos y forestales, así como la promoción y desarrollo agrario y la prestación de servicios comunes ${ }^{35}$.

\section{Algunos datos actuales}

Podemos considerar datos de la economía social española procedentes de dos fuentes, la citada investigación Las grandes cifras de la Economía Social en España, y los Anuarios que con el título La Economía Social en España publica la Confederación Empresarial española de la Economía Social (CEPES).

De la primera de ellas obtenemos el siguiente resumen referido al año 2008:

\begin{tabular}{|c|c|c|c|c|}
\hline Entidad & $\begin{array}{l}N^{\circ} \\
\text { entidades }\end{array}$ & $\begin{array}{l}\mathrm{N}^{\circ}{ }^{1} \\
\text { socios }^{1}\end{array}$ & $\begin{array}{l}\text { Empleos } \\
\text { directos }\end{array}$ & $\begin{array}{l}\text { Ventas } \\
\text { en euros }\end{array}$ \\
\hline Cooperativas & 24.738 & 6.774 .716 & 456.870 & 66.285 .893 .350 \\
\hline Sociedades Laborales & 17.637 & 82.894 & 133.756 & 12.095 .806 .704 \\
\hline Mutualidades & 428 & $2.450 .000^{2}$ & 8.700 & 6.141 .836 .456 \\
\hline $\begin{array}{l}\text { Centros Especiales de Em- } \\
\text { pleo }^{4}\end{array}$ & 1.775 & 52.631 & 52.631 & 1.067 .303 .310 \\
\hline Empresas de Inserción & 183 & 3.140 & 3.140 & 54.142 .735 \\
\hline Cofradías de Pescadores & 90 & 45.000 & 442 & 320.706 .792 \\
\hline Entidades Singulares ${ }^{5}$ & 3 & 924.276 & 65.603 & 2.818 .296 .000 \\
\hline Asociaciones $^{4}$ & 151.725 & 28.357 .403 & 470.348 & 22.642 .225 .200 \\
\hline $\begin{array}{c}\text { Fundaciones privadas al } \\
\text { servicio de los hogares }\end{array}$ & 4.279 & - & 52.106 & 4.878 .036 .000 \\
\hline Total & 200.858 & $38.690 .060^{3}$ & 1.243 .596 & 116.304.246.547 \\
\hline
\end{tabular}

Fuente: elaboración propia de un resumen del cuadro titulado «Magnitudes de la Economía Social en España», contenido en el informe Las grandes cifras de la Economía Social en España, p. 72).

1 Unas mismas personas pueden participar en diversas entidades por lo que el total de socios no lo es de diferentes personas.

2 Sin datos de las mutuas.

3 Corregido el total en 4.000 menos para cuadrar la suma.

4 No todos forman parte de la economía social.

5 Se trata de la ONCE, Cáritas Española, y Cruz Roja.

${ }^{6}$ Sus cifras de ventas corresponden a gastos, al igual que las de Cáritas Española y Cruz Roja.

35 Estatuto de Sociedades de Transformación, Real Decreto 1776/1981. 
Cabe destacar de estas cifras, la contribución de la economía social al empleo, de más de un millón doscientos mil empleos directos, que sobrepasa los dos millones si se contempla además del empleo directo el inducido, lo que supone algo más del $10 \%$ del empleo total, la facturación que alcanza el $10 \%$ del PIB, y el valor añadido bruto de esta economía social respecto al PIB del 2,47\% en $2008^{36}$.

De los últimos Anuarios del CEPES recojo los datos siguientes:

\begin{tabular}{lrrr}
\hline & 31.12 .2008 & 31.12 .2009 & 31.12 .2010 \\
\hline Cooperativas & 24.779 & 23.219 & 22.595 \\
Mutualidades & 403 & 403 & 402 \\
Asociaciones & 4.500 & 5.001 & 6.073 \\
Fundaciones de E.S. & 13 & 16 & 65 \\
Sociedades laborales & 17.650 & 15.679 & 14.574 \\
Cofradías de pescadores & - & 90 & 91 \\
Empresas de inserción & 150 & 154 & 193 \\
Centros especiales de empleo de la E.S. & 413 & 440 & 492 \\
Empresas E.S., otras fórmulas jurídicas & 85 & 91 & 208 \\
Entidades de economía social & 47.993 & 45.093 & 44.693 \\
Personas relacionadas económicamente & 2.354 .296 & 2.379 .994 & 2.377 .912 \\
$\quad$ con la E.S. & 115.069 & 92.157 & 86.663 \\
Facturación (en millones de euros) & 10.746 .962 & 12.150 .549 & 12.218 .185 \\
Asociacionismo ${ }^{2}$ & &
\end{tabular}

Fuente: elaboración propia a partir de los datos de los Anuarios de CEPES: La economía social en España 2008/2009, 2009/2010, y 2010/2011.

1 Socios, asalariados, autónomos.

2 Socios de ONCE, CERMI, ATLANTIS, Fundación Espriú, Socios no trabajadores en cooperativas y Mutualistas.

Si en 2008 la facturación representaba el 10\% del PIB ${ }^{37}$, la evolución de las cifras revela la situación de crisis profunda en la que está inmersa la economía española. Merece la pena destacar cómo si bien desciende el número de empresas y la facturación con la crisis, lo que se refiere a las personas sigue otra evolución, que vendrá a caracterizar a la economía social, toda vez que sube un poco y se mantiene el número de las personas relacionadas económicamente con la economía social, y sube con más intensidad la cifra de asociacionismo.

\footnotetext{
36 José Luis Monzón (dir.), o.c.(2010), p. 71.

37 La economía social en España 2008/2009 (2009), p. 18.
} 


\section{Consideraciones finales}

En este tiempo de final del siglo $x x y$ comienzos del siglo $x x$ en el que se ha ido consolidando el término de economía social, o al menos se ha avanzado considerablemente en el debate hasta el punto de la aprobación de la Ley de Economía Social en España, y también en Portugal, y, sobre todo, la presencia de sus agentes en la economía se ha incrementado y afianzado notablemente, seguramente resulta menos justificado reivindicar la cooperativización de la economía social ante la disparidad de agentes componentes de la misma, como hacía Joaquín Mateo en los años ochenta del pasado siglo ${ }^{38,}$ tratando de poner manifiesto el valor de la doctrina de las cooperativas, frente a otros agentes de la economía social con un menor soporte doctrinal.

Abundando en esto mismo, parece que se van superando posibles discrepancias de concepto a base de la aceptación y utilización de una terminología cada vez más amplia, y, en este sentido las referencias a la economía social y solidaria son habituales ${ }^{39}$. En Francia, señala Thierry Jeantet ${ }^{40}$, se avanza en la economía solidaria ante la falta de respuesta de la economía social para las personas con mayor dificultad. Otros consideran superada la preocupación por la conceptualización, quedando entonces como cuestión principal la relación con los poderes públicos ${ }^{41}$.

Tal vez como un reflejo de esa despreocupación por los conceptos se comience a usar el término emergente del «cuarto sector». Marta Enciso lo aborda de pasada y se refiere a «modelos de empresa que legalmente son de capital sin lugar a dudas, pero actúan en el mercado de manera diferente, basada en valores y en muchos casos con procesos de participación de sus trabajadores en gestión, beneficios y capital»42. Julio Jiménez y Alfonso Carlos Morales se detienen en esa realidad para identificar «entidades que muestran una habilidad especial para ocupar el espacio social que cruza los mundos público, pri-

38 Joaquín Mateo Blanco, «Algunas reflexiones sobre economía social»(1986), pp. 6-7.

39 Christine Collette y Benoît Pigé titulan Économie sociale et solidaire su libro de 2008; así también la OIT titula un documento de trabajo de 2011 Economía social y solidaria: nuestro camino común hacia el trabajo decente.

40 Thierry Jeantet, L'économie sociale: une alternative au capitalisme (2008), p. 39.

41 Bénédicte Fonteneau et al., Economía social y solidaria: nuestro camino común hacia el trabajo decente (2011), p. 49.

42 Marta Enciso Santocildes, «La Economía Social en España. La Ley 5/2011, de 29 de marzo» (2012), p. 116. 
vado capitalista y social (de la economía social) $\rangle^{43}$. Y estudian como protagonistas en este cuarto sector «... empresas sociales —un híbrido de negocio y organización no gubernamental-; fundaciones cívicas (community foundations) — híbrido entre fundaciones y asociaciones; y redes de solidaridad virtuales - una alternativa a organizaciones no gubernamentales tradicionales con formato de organización muy básico» ${ }^{44}$.

Esta evolución alrededor de los conceptos no significa en modo alguno la superación de la pluralidad de estatutos jurídicos de los diversos componentes de la economía social, de modo que, efectivamente, junto a unos elementos característicos compartidos, existen también grandes elementos diferenciadores, y, en consecuencia, será habitual que los agentes de la economía social traten de profundizar en la determinación de su propia identidad ${ }^{45}$.

Al mismo tiempo hay que reconocer la aportación de la economía social a la economía teniendo en cuenta, como observa Jeantet, que frente a un capitalismo concentrador y devastador la economía social está aliada con la Responsabilidad Social Empresarial, fortaleciendo los aspectos sociales y medioambientales de la economía, apostando por una economía sostenible ${ }^{46}$.

Además de su dimensión social debe valorarse la presencia de la solidaridad como característica de su funcionamiento, de forma que no sólo debe considerarse en sus empresas la eficacia económica sino una cualificación no económica de sus resultados ${ }^{47}$.

En un contexto de globalización la economía social ha centrado su atención en el desarrollo local y comunitario ${ }^{48}$, por lo que muchos países están considerando la economía social como motor para su desarrollo económico ${ }^{49}$.

43 Julio Jiménez Escobar y Alfonso Carlos Morales Gutierrez, «Social economy and the fourth sector, base and protagonist of social innovation»(2011), p. 44.

44 Julio Jiménez Escobar y Alfonso Carlos Morales Gutierrez, o.c. (2011), p. 45.

45 No es otra cosa la que hace la Agrupación de Sociedades Laborales de Euskadi (ASLE) cuando en su reciente Tercer Congreso, conmemorativo de su trigésimo aniversario, celebrado en Bilbao, el 15 de marzo de 2012, presenta un documento, titulado La sociedad laboral del siglo XXI, en el que propone que las sociedades laborales sean modelo de empresa participada, entendiendo por tal aquella que promueve y facilita que todos los trabajadores sean socios, a través de una participación directa en la que los trabajadores participan en el capital, o indirecta, cuando lo hacen a través de una sociedad tenedora de acciones.

46 Thierry Jeantet, o.c. (2008), pp. 18 ss.

47 Thierry Jeantet, o.c. (2008), p. 45.

48 Bénédicte Fonteneau et al., o.c. (2011), p. 146.

49 Thierry Jeantet, o.c. (2008), p. 39. 
Esta economía social, que prioriza el mantenimiento del empleo, que mantiene una dimensión social y solidaria, además de la propiamente económica, que promueve el desarrollo local y comunitario, que es respetuosa con el medio ambiente y valora la sostenibilidad, que conforma su actuación a unos principios... resulta perfectamente competente para afrontar los problemas económicos y sociales actuales.

Por ello, en este tiempo de crisis, como nos recuerda Joao Leite Salazar, la economía social es la parte menos afectada, por lo que si no es la solución, debe ser, por lo menos, una parte de ella ${ }^{50}$. Es la idea que recoge el Manifiesto de la Economía Social en Euskadi51, cuando señala que el compromiso para la creación y mantenimiento de los puestos de trabajo «... nos lleva a reivindicar, especialmente en la actual coyuntura, la apuesta por la Economía Social como una manera positiva de afrontar la crisis y de reconsiderar el papel que debe jugar la economía en nuestra sociedad».

Este Manifiesto, además de asumir unos compromisos y a partir de los mismos, plantea retos de futuro, entre los que encontramos:

- Profundizar en los valores y principios.

- Impulsar nuevos emprendimientos, para aumentar el empleo sostenible.

- Contribuir al desarrollo de la economía vasca con innovación y creatividad.

- Colaborar con otros para construir una economía y una sociedad con criterios de equidad, integración y solidaridad.

- Fomentar la intercooperación.

- Participar en redes internacionales de promoción del la economía social.

Todo ello marca las líneas por donde habrá de avanzar la economía social en el futuro.

50 Joao Leite Salazar, «Social Economy in Portugal» (paper, s.f.), p. 6

51 Manifiesto de las entidades de economía social agrupadas en KONFEKOOP-Confederación de Cooperativas de Euskadi, ASLE-Agrupación de Sociedades Laborales de Euskadi, EHLABE-Asociación de Entidades de Trabajo Protegido de Euskadi, GIZATEAAsociación de Empresas de Inserción del País Vasco, FUNKO-Confederación Vasca de Fundaciones, y Reas Euskadi-Red de Economía Alternativa y Solidaria, en Donostia-San Sebastián el 1 de febrero de 2012. 


\section{Bibliografía}

BOURSIER, François: "Aux origines de I'Economie Sociale», en Après-Demain, n. ${ }^{\circ}$ 270, Federation International des Droits de I'Homme, Paris, 1985, pp. 4-6.

CALDERÓN MILÁN, Beatriz: «Dimensión económica del sector no lucrativo en las regiones españolas», en CIRIEC-España, Revista de Economía Pública, Social y Cooperativa, $n .^{\circ}$ 50, 2004, pp. 231-245.

Cervera Paz, Ángel: Análisis estratégico de las cofradías de pescadores en el marco de la economía social, Tesis Doctoral, Universidad de Cádiz, Departamento de Organización de Empresas, Cádiz, 2006. En http://minerva.uca. es/publicaciones/asp/docs/tesis/cerverapaz.pdf

Collette, Christine et PIGÉ, Benoît: Économie sociale et solidaire. Gouvernance et contrôle, Dunod, Paris, 2008.

ChAVES, Rafael y MOnzón, José Luis: «Las cooperativas en las modernas economías de mercado: perspectiva española», en Economistas, n. ${ }^{\circ} 83$, Colegio de Economistas de Madrid, Madrid, 2000, pp. 113 a 123.

Defourny, Jacques: "Orígenes, contextos y funciones de un tercer gran sector», en J.L. Monzón y J. Defourny (dir.), Economía Social. Entre economía capitalista y economía pública, Ciriec-España ed., Valencia, 1992, pp. 79 a 104.

DesRoChe, Henri: Pour un traité d'Economie Sociale, CIEM, Paris, 1983.

—: La economía social en España 2008/2009, CEPES, Madrid, 2009.

—: La economía social en España 2009/2010, CEPES, Madrid, 2010.

—: La economía social en España 2010/2011, CEPES, Madrid, 2011.

Enciso SantoCiLdes, Marta: «La Economía Social en España. La Ley 5/2011, de 29 de marzo», en Felipe Gómez Isa et al. (eds.): Retos del Derecho ante una economía sin fronteras, Universidad de Deusto, Bilbao, 2012, pp. 109 a 116.

FAUQUet, Georges: «Le secteur coopératif», en Oeuvres, Publications de I'Institut des Etudes Coopératives, Paris, 1965, pp. 21-127.

FonteneAU, Bénédicte et al.: Economía social y solidaria: nuestro camino común hacia el trabajo decente, Documento de Trabajo de la OIT, 2. ${ }^{\text {a }}$ ed., Centro Internacional de Formación de la OIT, Turin, 2011.

HesselBACH, Walter: Las empresas de economía de interés general, siglo XXI editores, Madrid, 1978.

I.C.A.: Declaración de la Alianza Cooperativa Internacional sobre la identidad cooperativa, Consejo Superior de Cooperativas de Euskadi, Vitoria-Gasteiz, 1996.

Instituto de DeReChos Humanos: La economía solidaria y su inserción en la formación universitaria, Universidad de Deusto, Bilbao, 2004.

JEANTET, Thierry: L'économie sociale: une alternative au capitalisme, Economica, Paris, 2008.

-: La modernisation de la France par l'économie sociale, Ed. Economica, Paris, 1986.

- et Verdier, Roger: L'Economie Sociale, CIEM, Paris, 1982. 
Jiménez Escobar, Julio y Morales GutiérRez, Alfonso Carlos: "Social economy and the fourth sector, base and protagonist of social innovation», en CiriecEspaña, Revista de economía pública, social y cooperativa, n. 73, 2011, pp. 33 a 60.

Leite SAlAZAR, Joao: «Social Economy in Portugal», en www.cress-rhone-alpes. org/cress/lMG/pdf/Leite_pap.pdf, s.f., 8 ps.

LEY 5/2011, de 29 de marzo, de Economía Social.

Marcuello, Carmen; Bellostas, Ana y Marcuello, Chaime: Informe sobre la empresas de inserción en España, CIRIEC-España, Valencia, 2008.

MAREE, Michel y SAIVE, Marie-Anne: Economie sociale et renouveau coopératif: definition, financement, enjeux, CIRIEC, Liège, 1983.

Martínez ChARTERINA, Alejandro: Análisis de la integración cooperativa, Universidad de Deusto, Bilbao, 1990.

Mateo BlANCO, Joaquín: «Algunas reflexiones sobre economía social», en Boletín AECOOP, n. ${ }^{\circ} 124$, AECOOP, Madrid, 1986, pp. 4-7.

Monzón, José Luis (director): Las grandes cifras de la economía social en España, CIRIEC-España, Valencia, 2010.

-: «La economía social en España», en Ciriec-España, Revista de economía pública, social y cooperativa, n. ${ }^{\circ} 0,1987$, pp. 19 a 29.

- et al. (dirs.): El tercer sector no lucrativo en el Mediterráneo. La Economía Social de no mercado. Tomo I. CIRIEC-España, Valencia, 2003.

PeDREÑO, Juan Antonio: «Valoración de la Ley 5/2011 de Economía Social», en Cuadernos de Economía Social, n. 1, CEPES, Madrid, 2011, pp. 1-3.

RUIz OlABuénAGA, J.I.: El sector no lucrativo en España, Fundación BBVA, Madrid, 2000.

SAILLANT, Jean-Michel: "A la recherche de l'Economie Sociale», en Revue des études coopératives, n. ${ }^{\circ}$ 9, La Fondation du Crédit Coopératif, Nanterre Cedex, 1983, ps. 86-94.

SAlAMON, L. y ANHEIER, H.: In search of the nonprofit sector: The cuestion of definitions. Working papers. The Johns Hopkins University, Baltimore, 1992.

SOCial ECONOMy EuRope: Charte de l'économie sociale (Bruxelles, le 10 avril 2002), en www.socialeconomy.eu.org/spip.php?article262

VIENNEY, Claude: "Concepts et champs de l'Economie Social», en Revue des études coorératives, n. ${ }^{\circ}$, La Fondation du Crédit Coopératif, Nanterre Cedex, 1983, pp. 50-68.

WEISBROD, B.A.: «Toward a theory of the voluntary non-profit sector in a three sector economie», en E. Phelps, ed., Altruism, Morality and Economic Theory, Russel Sage Foundation, New York, 1975. 